\title{
Cakupan Alat Bukti sebagai Upaya Pemberantasan Kejahatan Siber (Cyber Crime)
}

\author{
Anis Dewi Lestari \\ Meliana Damayanti \\ Institut Agama Islam Negeri Surakarta (IAIN) Surakarta \\ Anisdewii96@gmail.com \\ iainmeliana@gmail.com
}

\begin{abstract}
The purpose of this research to know provisions about evidence as regulated in article 184 of the Criminal Procedure Code (KUHAP). The instruments of evidence consist of: witness evidence, expert evidence, written evidence, clue and confessions. The rapidity of information technology through the internet changes the activities of life that originally needed to do physical contact, now by using electronic media, everyday activities can be done in virtual or virtual. Faced with cybercrime case, due to proof of documentary, especially electronic documentary that does not meet the provisions of the criminal law system in Indonesia.

This research is a descriptive normative research in which this approach is done by emphasizing the law related to legal issues. To study and examine the laws relating to what cases exist on the internet, by doing research on written sources. The type of data used is secondary data, and this research technique by reviewing documents or written sources such as magazines, journals, books and others.

The results showed that with the existence of a tool of evidence accompanied by the judge's conviction. Elucidation of article 177 paragraph (1) letter $c$ of the draft Criminal Procedure Code "electronic evidence" means information uttered, transmitted, received, or stored electronically by optical or covert device with it, including records of readable data / information heard can be removed without the aid of a good means contained on paper and physical evidence.
\end{abstract}

Keywords: Cyber crime, evidence, internet

\begin{abstract}
Abstrak
Penelitian ini bertujuan untuk mengetahui ketentuan pembuktian sebagaimana diatur dalam pasal 184 Kitab Undang-Undang hukum Acara Pidana (KUHAP). Dalam pasal tersebut disebutkan alat-alat bukti terdiri atas : keterangan saksi, keterangan ahli, surat, petunjuk, keterangan terdakwa. Pesatnya Teknologi Informasi melalui internet tersebut mengubah
\end{abstract}


aktifitas-aktifitas kehidupan yang semula perlu dilakukan kontak fisik, sekarang dengan menggunakan media elektronik, aktifitas keseharian dapat dilakukan secara virtual atau maya. Namun demikian berhadapan dalam kasus siber (cyber crime) dalam hal pembuktian ternyata dokumen elektronik tidak memenuhi ketentuan sistem hukum pidana terutama dalam KUHP maupun KUHAP di Indonesia.

Penelitian ini merupakan penelitian normatif yang bersifat deskriptif dimana pendekatan ini dilakukan dengan cara menekankan pada undang-undang yang terkait dengan isu hukum. Untuk mempelajari dan menelaah hukum yang berkaitan dengan kasus apa saja yang ada di internet, dengan cara melakukan penelitian terhadap sumber-sumber tertulis. Jenis data yang digunakan adalah data sekunder, dan teknik penelitian ini dengan mengkaji dokumen atau sumber tertulis seperti majalah, jurnal, buku dan lain-lainnya.

Hasil penelitian tersebut menunjukkan bahwa dengan adanya sebuah alat bukti yang disertai dengan keyakinan hakim. Penjelasan pasal 177 ayat (1) huruf c RUU KUHAP yang dimaksud dengan "bukti elektronik" adalah informasi yang diucapkan, dikirim, diterima, atau disimpan secara elektronik dengan alat optik ataupun yang serupa dengan itu, termasuk rekaman data.

Key Words : kejahatan siber (cyber crime), alat bukti, internet

\section{PENDAHULUAN}

Pembuktian di era teknologi sekarang ini memerlukan tantangan besar yang memerlukan penanganan serius, khususnya dalam kaitannya dengan kejahatan dunia maya. Pembuktian dalam hukum pidana merupakan sub sistem kebijakan kriminal sebagai science of response yang mencakup berbagai disiplin ilmu. Hal ini disebabkan oleh luasnya jenis perkembangan teknologi informasi dewasa ini.

Terkait dengan ketentuan pembuktian sebagaimana diatur dalam pasal 184 Kitab Undang-Undang Hukum Acara Pidana (KUHAP) yang menyebutkan bahwa informasi elektronik seperti dalam pasal tersebut disebutkan alat-alat bukti terdiri atas : keterangan saksi, keterangan ahli, surat, petunjuk, dan keterangan terdakwa. (Mansur \& Gultom, 2003 : 105)

Pesatnya teknologi informasi melalui internet mengubah aktivitas-aktivitas kehidupan yang semula perlu dilakukan kontak fisik, sekarang dengan menggunakan media elektronik, aktivitas keseharian dapat dilakukan secara virtual atau maya. Berhadapan dengan kasus kejahatan siber (cybercrime), pembuktian menjadi pokok masalah yang penting, seringkali mengalami kesulitan saat menjerat pelaku kejahatan siber (cyber crime), karena pembuktian terkait bukti yang berupa dokumen tidak memenuhi ketentuan sistem hukum pidana di Indonesia.

UU ITE No 19 Tahun 2016 telah mempertegas hasil cetak (print out) sebagai alat bukti. la menunjuk pada Pasal 5 ayat (1), dimana dirumuskan : informasi elektronik dan/ atau Dokumen Elektronik dan/atau hasil cetaknya merupakan alat bukti hukum yang sah.

al-aḥkām vol. 3, Nomor 1, 2018 
Selain itu, UU ITE telah mengatur tata cara perolehan informasi elektronik sebagai alat bukti (pasal 43 ayat 3) dan tata cara pengajuan informasi elektronik sebagai alat bukti (pasal 5 ayat 3 jo pasal 16). Menurut Brian, UU ITE memiliki tiga keuntungan yaitu lebih memberikan kepastian hukum, lingkup keberlakuannya lebih luas, dan lebih harmonis dengan lingkungan internasional. (Hamdi, Suhaimi, \& Mujibussalim, 2003)

Dalam penelitian yang berjudul kekuatan pembuktian Alat Bukti Informasi Elektronik dan dokumen elektronik serta Hasil cetaknya dalam pembuktian pidana didalam hal tersebut menggunakan aturan baru di Indonesia dalam UU Nomor 19 tahun 2016 tentang UU ITE. Lebih menekankan pada alat bukti hasil cetaknya yang menjadi perluasan alat bukti surat atau alat bukti petunjuk yang diatur dalam pasal 5 UU ITE. Tetapi alat bukti informasi tidak bisa dijadikan perluasan sumber perolehan alat bukti karena keberadaan alat bukti petunjuk digunakan setelah menghadirkan alat bukti lain. (Barama, 2016)

Berdasarkan berbagai penelitian yang telah dilakukan sebelumnya oleh beberapa peneliti lain seperti yang telah disebut diatas. Maka dalam penelitian ini lebih menekankan pada cakupan alat bukti konvensional yang dipakai di dalam Kitab Undang-Undang Hukum Acara Pidana (KUHAP) yang aturannya berada di dalam Undang-Undang informasi dan Transaksi Elektronik (UU ITE) terbaru yaitu Undang-Undang Nomor 19 Tahun 2016 yang pembahasannya lebih menekankan pada Dokumen Elektronik yang menjadi perluasan alat bukti pada kasus kejahatan siber (cyber crime).

Adapun penelitian jenis ini menggunakan metode penelitian kepustakaan dengan membaca buku-buku, jurnal-jurnal hukum, undang undang yang berkaitan dengan topik yang akan dibahas. Dimana keseluruhan dari hasil penelitian tersebut dikumpulkan dan dianalisa sesuai kebutuhan penulis dengan menggunakan metode:

1. Metode deduktif adalah pembahasan yang berkaitan dengan bertitik tolak pada ketentuan yang bersifat umum untuk ditarik dalam suatu kesimpulan yang bersifat khusus.

2. Metode induktif yaitu pembahasan suatu hal yang mempunyai sifat khusus kemudian ditarik di dalam kesimpulan yang bersifat umum. Metode tersebut digunakan secara silih berganti sesuai kebutuhan.

Agar penelitian ini lebih tajam dalam menganalisa, maka peneliti merumuskan tiga permasalahan yang menjadi tolak ukur dalam penelitian ini. Yakni : bagaimana pengunaan alat bukti elektronik dalam kasus kejahatan siber (cyber crime) menjadi penting? bagaimana pengunaan alat bukti konvensional dalam kasus kejahatan siber (cyber crime) ? serta bagaimana perluasan alat bukti pada tindak pidana dunia maya? 


\section{Alat Bukti Elektronik Dalam Kasus Kejahatan Siber (Cyber Crime)}

Undang-Undang Dasar Negara Republik Indonesia 1945, dalam pasal 1 ayat (3) menyebutkan bahwa Indonesia adalah Negara Hukum yang pemerintahannya di dasarkan pada prinsip-prinsip hukum yang sifatnya universal dan kearifan lokal. Prinsip universal yaitu landasan filosofi dan teori yang digunakan untuk membentuk perspektif dan implementasi yuridis yang mendasari ketatanegaraan Indonesia.

Prinsip Negara hukum pada masa yang akan datang mengalami sebuah tantangan yang sangat besar. Dulu yang terjadi adalah revolusi industri, tetapi saat ini yang terjadi revolusi teknologi yang semakin berkembang, baik dilihat dari dampak positifnya maupun sebaliknya. Revolusi teknologi yang akan datang merubah paradigma, semua bidang dan termasuk hukum dituntut untuk beradaptasi. Seperti yang telah kita ketahui dalam penyebaran sebuah berita saat ini sudah mengalami perubahan, seperti sms, email, whatsapp, telegram, line, video call semuanya berbasis aplikasi yang memudahkan kita untuk mendapatkannya secara mudah. Bahkan dulu media televisi adalah hiburan pertama bagi masyarakat Indonesia tetapi saat ini hanya dengan menekan youtube yang memudahkan seseorang melihat dan meng-upload sebuah berita yang menjadikan tontonan tanpa biaya.

Contoh yang nyata dalam lingkungan peradilan misalnya sistem kepegawaian secara otomatis perpajakan yang dikelola secara elektronik sehingga potensi kebocoran keuangan negara dapat dideteksi mulai dari sekarang. Tanpa di sadari atau tidak, baik Mahkamah Agung tingkat pertama maupun banding sudah memiliki website sendiri untuk memudahkan dalam mengurus perkara, info perkara dan bantuan panggilan sidang secara elektronik. Termasuk dalam pengunaan tele-conference untuk memonitoring akreditas pengadilan dan mengevaluasi serta e-monitoring. (Abdullah, Gelombang Online Dalam Perkembangan Hukum, 2018)

Sistem hukum pembuktian sampai saat ini masih menggunakan ketentuan hukum yang lama, dan belum mampu menjangkau pembuktian atas kejahatan-kejahatan yang berlaku di lingkungan dunia maya. Namun keberadaan Undang-Undang No. 8 tahun 1997 tentang Dokumen Perusahaan telah mulai menjangkau ke arah pembuktian dalam data elektronik. Walaupun Undang-Undang tersebut tidak mengatur masalah pembuktian, pemerintah berusaha mengatur pengakuan atas microfim dan media lainnya. Dalam pasal 12 Undang-Undang Nomor 8 tahun 1997 tentang dokumen perusahaan sebagai alat bukti yang sah.

Pasal 12 Undang-Undang Dokumen Perusahaan tersebut berbunyi sebagai berikut:

1. Dokumen Perusahaan dapat dialihkan ke dalam mikrofilm atau media lainnya.

2. Pengalihan dokumen perusahaan ke dalam mikrofilm atau media lainnya sebagaimana dimaksud dalam ayat (1) dapat dilakukan sejak dokumen tersebut dibuat atau diterima oleh perusahaan yang bersangkutan.

al-ạ̣kān Vol. 3, Nomor 1, 2018 
3. Dalam mengalihkan dokumen perusahaan sebagaimana dimaksud dalam ayat (1), pimpinan perusahaan wajib mempertimbangkan kegunaan naskah asli dokumen yang perlu tetap disimpan karena mengandung nilai tertentu demi kepentingan perusahaam atau demi kepentingan nasional.

4. Dalam hal dokumen perusahaan dialihkan di dalam microfilm atau sarana lainnya bisa naskah asli yang mempunyai kekuatan hukum pembuktian otentik dan masih mengandung kepentingan hukum tertentu, pimpinan perusahaan wajib tetap menyimpan naskah asli tersebut.

Disamping itu dalam Pasal 3 undang-undang tentang dokumen perusahaan telah memberi peluang luas terhadap pemahaman atas alat bukti yaitu "dokumen keuangan terdiri dari catatan, bukti pembukuan, dan delik pendukung administrasi keuangan, yang merupakan bukti adanya hak dan kewajiban serta kegiatan usaha suatu perusahaan.

Pasal 4 menyatakan "dokumen lainnya terdiri dari data atau setiap tulisan yang berisi keterangan yang mempunyai nilai guna bagi perusahaan meskipun tidak terkait langsung dengan dokumen perusahaan".

Sebuah dokumen baru mempunyai kekuatan sebagai alat bukti setelah dilakukan proses legalisasi yang dilakukan oleh pemimpin perusahaan yang ditunjuk di lingkungan perusahaan tersebut, berita acara yang dimaksud adalah keterangan tempat, keterangan pengalihan dokumen perusahaan serta tanda tangan dan nama jelas yang bersangkutan hal tersebut diatur dalam pasal 13 dan pasal 14 undang-undang dokumen perusahaan.

Mengenai keabsahan transaksi dan kekuatan pembuktian, transaksi elektronik tidak memerlukan hard copy atau warkat kertas, namun dalam transaksi yang melibatkan eksekusi diberikan tanda bukti berupa nomer atau kode yang bisa disimpan/direkam di komputer atau dicetak. ketentuan mengenai transaksi elektronik diakui sederajat dengan "tulisan" diatas kertas oleh UNICTRAL (United Nation Commision On International Trade) yang mencantumkan dalam e-commerce model hukum, sehingga tidak bisa ditolak sebagai bukti pengadilan. (Mansur \& Gultom, 2005)

Informasi Elektronik hanya terbatas dengan orang yang mampu memahami Informasi yang selanjutnya dalam mengartikan Informasi Elektronik tersebut, dalam Pasal 1 angka 4 menggunakan sarana komputer dan sistem elektronik dengan menerjemahkan Informasi yang ada dalam Dokumen Elektronik. Sistem Elektronik yaitu serangkaian perangkat dan prosedur elektronik yang berfungsi mempersiapkan, mengumpulkan, mengolah, menganalisis, menyimpan, menampilkan, mengumumkan, mengirimkan, dan/ atau menyebarkan Informasi Elektronik (Penjelasan Pasal 1 angka 5 Undang-Undang No. 19 tahun 2016 mengatur tentang Informasi dan Transaksi Elektronik). maka pengungkapan fakta ketiga putusan diatas harus bisa membedakan Informasi Elektronik dan Dokumen Elektronik untuk meminimalisir multitafsir yang mungkin terjadi oleh hakim pengadilan. 
(Handoko, 2016)

Proses pembuktian pada kasus kejahatan siber (cyber crime) pada dasarnya tidak berbeda dengan pembuktian pada kasus pidana konvensional, tetapi dalam kasus kejahatan siber (cyber crime) terdapat ada beberapa hal yang bersifat elektronik yang menjadi hal utama dalam pembuktian, diatur dalam pasal 5 ayat (1) dan (2) Undang-Undang Nomor 19 Tahun 2016 bahwa Informasi dan Dokumen Elektronik (UU ITE) dianggap sebagai alat bukti yang sah dalam proses pembuktian dan hal yang berkaitan dengan perbuatan hukum yang dilakukan oleh Sistem Elektronik pada kasus kejahatan siber (cyber crime).

Dalam membuktikan suatu tindak pidana diharuskan ada dua alat bukti yang disertai dengan keyakinan hakim. Menurut penjelasan pasal 177 ayat (1) huruf c RUU KUHAP yang dimaksud dengan "bukti elektronik" adalah informasi yang diucapkan, dikirim, diterima, atau disimpan secara elektronik dengan alat optik atau yang serupa dengan itu, termasuk rekaman data/informasi yang dapat dilihat, dibaca, dan didengar dapat dikeluarkan tanpa bantuan suatu sarana baik yang tertuang diatas kertas, benda fisik apapun selain kertas maupun yang terekam secara elektronik berupa tulisan, gambar, peta, rancangan, foto, huruf, tanda, angka atau perforasi yang memiliki makna. (Hamdi, Suhaimi, \& Mujibussalim, 2003)

Bukti elektronik masuk didalam kategori bukti yang sudah ada artinya bukti tersebut tidak berdiri sendiri seperti yang telah dilihat dalam Undang-Undang Nomor 8 Tahun 1997 tentang Dokumen Perusahaan bahwa alat bukti elektronik tidak dapat berdiri sendiri karena perluasannya di atur dalam Pasal 184 KUHAP. Serta bagian dari dokumen elektronik bagian dari dokumen perusahaan dan dokumen perusahaan merupakan alat bukti dari surat. Demikian pula dalam undang-undang Nomor 20 Tahun 2001 tentang perubahan atas Undang-Undang Nomor 31 Tahun 1999 tentang pemberantasan Tindak Pidana Korupsi bahwa alat bukti elektronik merupakan perluasan dari alat bukti yang sah berupa petunjuk.

Peraturan Undang-Undang yang lain memberikan pengakuan terhadap Dokumen Elektronik dalam Undang-Undang nomor 7 tahun 1971 tentang Sistem Kearsipan, menyatakan bahwa suatu informasi elektronik tetap diakui, karena definisi kearsipan tidak pernah menyatakan arsip dalam bentuk tertulis dalam media kertas tetapi dimungkinkan untuk disimpan dalam media lainnya.

Dalam Undang-Undang tersebut yang dimaksud dengan arsip ialah :

A. Naskah tersebut dibuat dan diterima oleh lembaga negara dan badan pemerintahan dalam bentuk corak apapun.

B. Naskah tersebut dibuat dan diterima oleh badan swasta atau perorangan, dalam bentuk corak apapun. Mengenai kemanan data, Undang-Undang ini mencantumkan ancaman pidana terhadap siapa saja yang melawan hukum atau menyimpan serta dengan sengaja memberitahukan isi arsip kepada pihak ketiga yang tidak 
mengetahuinya. (Isma \& Koyimatun, Jurnal IImu Hukum No.4 Juli 2014 : 111-112)

Macam macam sistem pembuktian

1. Sistem pembuktian berdasarkan pada Undang-Undang secara positif

2. Teori pembuktiannya berdasarkan secara negatif

Artinya teori ini menyadarkan bahwa hakim dalam mengambil keputusan baik/ tidaknya seorang terdakwa terikat oleh alat bukti yang ditentukan oleh UndangUndang dan keyakinan hakim sendiri. Dalam sistem ini dikenal dua hal yang merupakan syarat untuk membuktikan kesalahan terdakwa, yaitu alat bukti yang sah dan telah diterapkan dengan adanya keyakinan hakim berdasarkan bukti bukti tersebut hakim menyakini kesalahan terdakwa.

3. Sistem atau teori pembuktian berdasarkan keyakinan hakim melulu (conviction in time)

Dalam teori ini, menjatuhkan putusan hakim tidak terikat pada bukti yang ada. Hakim menyimpulkan putusannya tidaklah menjadi masalah, karena ia dapat menyimpulkan alat bukti yang ada dalam persidangan atau mengabaikan alat bukti tersebut.

4. Sistem atau pembuktian berdasarkan keyakinan hakim atas alasan yang logis (conviction raisonnee)

Hakim dalam memutuskan seseorang bersalah berdasarkan keyakinan dan alasan alasan yang logis. Bisa disebut juga pembuktian bebas karena hakim bebas untuk menyebut alasan-alasan keyakinannya. Dalam hal ini Indonesia sendiri menganut sistem tersebut.

Berkenaan dengan hukum pembuktian dalam proses peradilan dalam perkara pidana, kemajuan teknologi memunculkan persoalan teesendiri mengenai hukum pembuktian yang ada saat ini dan telah menjangkau adanya kasus kasus cybercrime. Khususnya catatan atau Dokumen Elektronik masih menjadi bahan perdebatan mengenai bagaimana kedudukannya sebagai alat bukti yang sah di persidangan. (Mansur \& Gultom, 2005)

Masalah yang dihadapi penegak hukum saat ini adalah bagaimana menjaring pelaku kejahatan teknologi informasi yang mengusik rasa keadilan yang dikaitkan dengan ketentuan pidana yang berlaku. Mengingat kelemahan KUHAP tersebut, dalam menjalankan tugasnya penyidik harus dengan cerdik menggunakan definisi dokumen elektronik yang dapat diterima sebagai alat bukti. yang dimaksud pada pasal 1 nomor (2) UU ITE "Transaksi Elektronik adalah perbuatan hukum yang dilakukan dengan menggunakan komputer, jaringan atau media lainnya". Dalam rangka melakukan Transaksi Elektronik, maka para pihak akan selalu menggunakan suatu Dokumen Elektronik sebagai landasan bagi mereka 
untuk melakukan perbuatan yang melawan hukum.

\begin{tabular}{|c|c|}
\hline $\begin{array}{l}\text { Kitab undang-undang hukum } \\
\text { acara pidana (KUHAP) }\end{array}$ & $\begin{array}{c}\text { Undang-Undang Nomor 19 Tahun } \\
2016 \text { tentang Informasi dan Transaksi } \\
\text { Elektronik (UU ITE) }\end{array}$ \\
\hline Keterangan saksi & Keterangan Saksi \\
\hline Keterangan Ahli & Keterangan Ahli \\
\hline Surat & Surat \\
\hline Petunjuk & Petunjuk \\
\hline Keterangan Terdakwa & - \\
\hline
\end{tabular}

Berdasarkan KUHAP dan Undang-Undang Nomor 19 Tahun 2016 tentang Informasi dan Transaksi Elektronik, dalam kejahatan siber (cyber crime) alat bukti yang dapat digunakan adalah sebagai berikut :

a) Keterangan saksi

Diatur dalam KUHAP pasal 1 angka 27 KUHAP dinyatakan "keterangan saksi adalah satu dari alat bukti dalam perkara pidana yang berupa keterangan dari saksi mengenai suatu peristiwa pidana yang ia dengar sendiri, ia lihat sendiri, ia alami sendiri dengan menyebut pengetahuannya itu."

Dalam cyber crime diatur pada Pasal 7 Undang-Undang No. 19 Tahun 2016 tentang UU ITE keterangan tersebut dalam perkara kejahatan siber (cyber crime) bisa di jadikan pertimbangan hakim dalam memutus perkara. Yang berbunyi "setiap orang yang menyatakan hak, memperkuat hak yang telah ada, atau menolak hak orang lain berdasarkan adanya Informasi Elektronik dan/ atau Dokumen Elektronik harus memastikan bahwa Informasi Elektronik dan/ atau Dokumen Elektronik yang ada padanya berasal dari Sistem Elektronik yang memenuhi syarat berdasarkan Peraturan Perundang-undangan".

Dalam undang-undang UU ITE seorang saksi yang ingin memberikan keterangannya tidak perlu datang ke pengadilan, dan bisa melalui media komunikasi. Hal tersebut diatur dalam pasal 44 UU ITE yang menyebutkan bahwa "alat bukti penyidikan penuntutan dan pemeriksaan sidang pengadilan menurut ketentuan Undang-Undang ini adalah sebagai berikut : alat bukti sebagaimana dimaksud dalam ketentuan perundang-undangan, alat bukti berupa Informasi Elektronik dan/ atau Dokumen Elektronik sebagaimana dimaksud dalam Pasal 1 angka 1 dan angka 4 serta Pasal 5 ayat (1), ayat (2), dan ayat (3)".

Sesuai dengan gambaran diatas diatur dalam pasal 1 ayat (27) KUHAP bahwa saksi dalam memberikan keterangan saksi harus wajib hadir dipengadilan yang dibuka 
untuk umum ketentuan tersebut diatur dalam pasal 16 KUHAP.

b) Keterangan Ahli

Keterangan ahli menurut pasal 1 angka (28) KUHAP adalah seseorang yang mempunyai keahlian khusus untuk menjelaskan sesuai ahlinya.

Dalam perkara cyber crime seorang ahli dituntut untuk memberikan keterangan yang alurnya terjadi di dunia maya, hal tersebut dijelaskan pada pasal 1 ayat (1) UU ITE, tuntutan terhadap saksi ahli dalam menerjemahkan kejadian yang diungkapkan oleh saksi dan terdakwa.

c.) Surat

Berdasarkan Pasal 187 KUHAP diuraikan tentang alat bukti surat yang terdiri dari 4 (empat) butir. Dokumen Elektronik tidaklah dapat dijadikan alat bukti jika terhadap suatu surat, Undang-Undang menentukan harus dibuat dalam bentuk tertulis, termasuk pula akta notaris atau akta yang dibuat oleh pejabat pembuat akta.

alat bukti surat yang dipakai dalam pembuktian Kejahatan siber (cyber crime) merupakan alat bukti yang sah sepanjang itu sesuai dengan sistem elektronik yang di atur dalam undang-undang pasal 5 ayat (1) UU ITE.

d) Petunjuk

Alat bukti petunjuk merupakan hak hakim yang memeriksa perkara tersebut. Hakim harus menghubungkan alat bukti yang satu dengan yang lain. Penilaian atas kekuatan pembuktian suatu petunjuk dalam setiap keadaan tertentu dilakukan oleh hakim setelah ia mengadakan pemeriksaan. Tegasnya, syarat-syarat petunjuk sebagai alat bukti harus mempunyai persesuaian satu sama lain atas perbuatan yang terjadi. Keadaan-keadaan tersebut berhubungan dengan kejahatan yang terjadi dan berdasarkan pengamatan hakim yang diperoleh dari keterangan saksi, surat dan keterangan terdakwa.

e) Keterangan Terdakwa

Pembuktian perkara Pidana diatur dalam Hukum Acara Pidana yang tetap diperlukan sekalipun terdakwa mengakui tindak pidana yang didakwakan kepadanya. dalam Pasal 1 ayat (15) KUHAP adalah seseorang tersangka yang dituntut, diperiksa, dan di adili di sidang pengadilan. (Handoko, 2016)

Menurut Pasal 189 ayat (1) KUHAP, "Keterangan terdakwa adalah apa yang terdakwa nyatakan di sidang tentang perbuatan yang dilakukan atau yang ia ketahui sendiri atau ia alami sendiri". Keterangan terdakwa yang diberikan di luar sidang dapat digunakan untuk membantu menemukan bukti di sidang, keterangan itu didukung oleh suatu alat bukti yang sah sepanjang mengenai hal yang didakwakan kepadanya. 
Syarat syarat adanya transaksi elektronik

1. Lembaga sertifikasi keandalan, melakukan fungsi administrasi yang dapat mencakup otentik fisik terhadap pelaku usaha, pembuatan dan pengelolaan sertifikat keandalan dan membuat daftar sertifikat yang telah dibekukan, Hal tersebut di atur dalam pasal 10 UU ITE.

2. Penyelenggara sertifikat elektronik melakukan fungsi administrasi dapat mencakup data otentik fisik terhadap pemohon dalam pembuatan serta pengelolaan sertifikat elektronik, hal tersebut di atur dalam pasal 13 dan 14 UU ITE.

Ketentuan pasal 5 ayat (3) UU ITE bahwa "Informasi Elektronik atau Dokumen Elektronik dinyatakan sah apabila menggunakan sistem Elektronik, dengan demikian Dokumen Eletronik sebagai suatu alat bukti yang sah jika menggunakan sistrem elektronik. Dalam rangka pembuatan suatu perjanjian atau Transaksi Elektronik dituangkan dalam bentuk Dokumen Elektronik, suatu Dokumen Elektronik harus memuat tanda-tangan bentuk elektronik".

Tanda tangan elektronik mempunyai kekuatan hukum yang sah apabila memenuhi persyaratan yang ditentukan dalam pasal 11 UU ITE :

1) Data pembuatan tanda tangan elektronik hanya kepada pihak yang bersangkutan

2) Data pembuatan tanda tangan elektronik, saat proses penandatanganan hanya berada dalam kuasa penandatangan.

3) Perubahan terhadap tanda tangan elektronik terjadi waktu penandatanganan dapat diketahui,

4) Ada cara tertentu untuk menunjukkan bahwa para pihak yang melakukan tanda tangan telah memberikan suatu persetujuan alat elektronik terkait.

Dalam praktek peradilan, sikap hakim memandang suatu alat bukti elektronik sangat beragam, seperti alat bukti elektronik adalah bukti yang sah sebagai tambahan alat bukti konvensional didalam Hukum Acara Pidana, dan bisa juga sebagai alat bukti pendamping untuk menambah keyakinan hakim. Hakim menilai alat bukti Dokumen Elektronik sebagai persangkaan, karena pembuktiannya harus didukung oleh 2 (dua) orang saksi yang secara langsung melihat kejadian tersebut. Dan pada dasarnya alat bukti elektronik tidak bisa berdiri sendiri. Melainkan harus didukung dengan alat bukti lainnya. (wahyudi, 2014)

Kelman menyatakan ada tiga tpe pembuktian yang dibuat oleh komputer

1. Real Evidence (bukti nyata)

Real evidence (bukti nyata), bukti tersebut meliputi kalkulasi (perhitungan) atau analisa yang dibuat oleh komputer itu sendiri melalui aplikasi software dan penerima informasi dari devise lain. Bukti nyata tersebut muncul dari berbagai kondisi. Seperti bank yang 
secara otomatis menghitung nilai pembayaran pelanggan terhadap bank berdasarkan tarifnya, maka perhitungan tersebut akan menjadi sebuah bukti nyata.

2. Hearsay evidence (bukti yang berupa dari kabar orang lain)

Sebuah dokumen-dokumen data yang diproduksi oleh komputer dan merupakan salinan dari informasi yang diberikan dan di data oleh seseorang kepada komputer. Seperti cek yang ditulis pada lip pembayaran yang diambil dari rekening bank juga termasuk dalam hearsay evidence.

3. Derived evidence bahwa informasi yang diperoleh dari bukti nyata yang diberikan oleh manusia ke di komputer dengan tujuan membentuk data yang tergabung. (Mansur \& Gultom, 2005)

\section{Alat bukti konvensional dalam kasus kejahatan siber (cyber crime)}

Proses penegakan hukum tidak terlepas dari dalih-dalih kesulitan. Apabila jika perbuatan cyber crime dapat digunakan delik-delik konvensional yang ketentuannya jelas dan tegas. Pemerintah bersama DPR telah bersepakat dalam memulai pembahasan draf Revisi KUHAP dan KUHP, dimana publik melirik apa saja yang termuat dari RUU tahun 2008 yang mengakomodasi perkembangan teknologi informatika sebagai salah satu alat bukti. Didalam peradilan Negara Indonesia dikenal 5 (lima) macam alat bukti yang dapat dipergunakan dipersidangan sebagaimana diatur dalam KUHAP. Dalam draf RUU KUHAP Tahun 2008, alat bukti yang sah dipersidangan berubah menjadi ;

a) Barang bukti

b) Surat-surat

c) Alat bukti elektronik

d) Keterangan saksi

e) Keterangan ahli

f) Keterangan terdakwa

Tergantung pada pembahasan komisi III, jika tidak ada lagi Undang-Undang yang mengatur kecuali KUHAP maka pihak KPK ikut menggunakan KUHAP tersebut. Dalam penggunaan alat bukti konvensional atas kejahatan siber (cyber crime), hakim memegang peranan penting dalam penyelesaian perkara dengan wajib menggali hukum yang hidup dalam masyarakat. Hakim harus membuat trobosan hukum jika belum ada UndangUndang yang mengaturnya. Peranan hakim dalam kasus kejahatan siber (cyber crime) harus mempunyai kemampuan dalam teknologi informasi dan pandangan yang luas dalam penafsiran hukum. (Natalia, 2015) 


\section{Karateristik kejahatan siber/ telematika}

Tindakan kejahatan tradisional umumnya meninggalkan buti fisikal, karena proses dan hasil kejahatan berhubungan dengan benda berwujud nyata. Dalam dunia komputer dan interne, tindakan kejahatan akan melalui proses yang sama. Perbedaan karateristik antara kejahatan konvensional yang berbasis sitem manual dalam kejahatan modern yang berbasis computerized/ electronic. Perbedaan dalam karateristik berawal dari perbedaan proses yang dapat dideskripsikan pada bagan sebagai berikut:

\begin{tabular}{|c|c|c|}
\hline Kriteria & SISTEM MANUAL & SISTEM ELEKTRONIK \\
\hline Tampilan Data & $\begin{array}{l}\text { Tercetak langsung pada kertas } \\
\text { sehingga bersifat nyata }\end{array}$ & $\begin{array}{l}\text { Terkopi dalam media penyimpanan } \\
\text { elektronik (floopy disk, compact } \\
\text { disc, hard disc dll) sehingga bersifat } \\
\text { virtual dan intangible) }\end{array}$ \\
\hline Sifat Data & $\begin{array}{l}\text { Tidak sensitif yang artinya setiap } \\
\text { perubahan terhadapnya (misal } \\
\text { dipalsukan) selalu meninggalkan } \\
\text { bekas. Perubahan resmi selalu } \\
\text { disertai validasi }\end{array}$ & $\begin{array}{l}\text { Data bersifat sensitif sehingga jika } \\
\text { ada suatu perintah atau interaksi } \\
\text { elektronik tertentu, dapat berubah } \\
\text { tanpa meninggalkan bekas }\end{array}$ \\
\hline Akses & $\begin{array}{l}\text { Kunci manual atau kunci dengan } \\
\text { nomor kombinasi }\end{array}$ & $\begin{array}{l}\text { Keying User ID, PIN Test Key atau } \\
\text { password }\end{array}$ \\
\hline $\begin{array}{l}\text { Penelusuran/ } \\
\text { Pencurian }\end{array}$ & $\begin{array}{l}\text { Daftar indeks atau katalog } \\
\text { (langsung membuka arsip) }\end{array}$ & $\begin{array}{l}\text { Secara elektronik, dengan } \\
\text { mengetikkan katakuncipada search } \\
\text { engine atau program elektronik } \\
\text { yang lain }\end{array}$ \\
\hline Transaksi & $\begin{array}{l}\text { - Paper Based; yang secara nyata } \\
\text { (Uang Tunai, cek, giro dll) } \\
\text { - Pihak-pihak: jelas } \\
\text { - Validasi: Tanda tangan, paraf } \\
\text { atau stempel (yang berfungsi } \\
\text { sebagai pengakuan dan } \\
\text { penerimaan atas isi pesan } \\
\text { maupun dokumen) }\end{array}$ & $\begin{array}{l}\text { - Paperless (scriptless): secara } \\
\text { digital melalui sinyal elektronis } \\
\text { (ATM, EFT, e-commerce, } \\
\text { e-banking dll } \\
\text { - Validasi : Tanda tangan Elektronik } \\
\text { bahkan tanpa validasi sama sekali } \\
\text { (Digital Signature berfungsi } \\
\text { sebagai message intergrity) }\end{array}$ \\
\hline Privacy & $\begin{array}{l}\text { Dibatasi ruang dan waktu secara } \\
\text { fisik (badan, rumah, pekarangan } \\
\text { dll.) }\end{array}$ & $\begin{array}{l}\text { Tidak dibatasi secara fisik (computer } \\
\text { network, cyberspace, LAN, WAN } \\
\text { dll.) }\end{array}$ \\
\hline
\end{tabular}

Dari sekilas gambaran di atas, bahwa persoalan pada dasarnya adalah perubahan dari hal-hal yang bersifat nyata pada proses manual menjadi sesuatu yang bersifat nyata/ tangible pada proses manual menjadi suatu yang bersifat tidak nyata/ intangible pada proses komputerisasi. Hal ini disebabkan karena adanya objek yang bersifat fisik yang dapat dilihat dan diraba kini telah digantikan dengan denyut elektronik. 
Perbedaan yang cukup mendasar antara prosedur dalam sistem manual dengan elektronik berpengaruh besar terhadap perbedaan bentuk dan sifat antara kejahatan konvensional dan kejahatan telematika.

Kejahatan-kejahatan tersebut dapat dideskripsikan dalam tabel :

\begin{tabular}{|l|l|l|}
\hline \multicolumn{1}{|c|}{ Kriteria } & \multicolumn{1}{|c|}{ Kejahatan Konvensional } & \multicolumn{1}{c|}{ Kejahatan telematika } \\
\hline Alat/Sarana & $\begin{array}{l}\text { Tradisional (seperti kunci } \\
\text { palsu, surat/dokumen palsu, } \\
\text { senjata api/tajam, kendaraan } \\
\text { dll.) }\end{array}$ & $\begin{array}{l}\text { Teknologi (komputer, telepon/HP, } \\
\text { internet, magnetic card dII) }\end{array}$ \\
\hline Sasaran & $\begin{array}{l}\text { Barang atau jasa serta aset } \\
\text { nyata yang bernilai ekonomis }\end{array}$ & $\begin{array}{l}\text { Barang, jasa, informasi, data, program, } \\
\text { HaKI yang bernilai ekonomis }\end{array}$ \\
\hline Pelaku & $\begin{array}{l}\text { Bisa siapa saja karena pelaku } \\
\text { tidak memikirkan akibatnya } \\
\text { terlebih dahulu }\end{array}$ & $\begin{array}{l}\text { Perlu memiliki kemampuan intelektual } \\
\text { yang tinggi dan profesional karena } \\
\text { unsur otak sangat dominan }\end{array}$ \\
\hline Ruang lingkup & $\begin{array}{l}\text { Mudah menentukan batas } \\
\text { yurisdikasinya }\end{array}$ & $\begin{array}{l}\text { Transasional dan borderland (antara } \\
\text { pelaku, korban, dan bisa berada pada } \\
\text { wilayah yang negara yang berbeda }\end{array}$ \\
\hline Modus operandi & $\begin{array}{l}\text { Relatif sederhana, mudah } \\
\text { teridentifikasi }\end{array}$ & $\begin{array}{l}\text { Lebih kompleks, } \\
\text { berkembang cepat (adaptasi teknologi } \\
\text { dan sistem) }\end{array}$ \\
\hline
\end{tabular}

Dalam paparan tabel di atas bahwa kejahatan telematika mempunyai karateristik yang khas : terkait dengan subjek yang tidak nyata, maka dari itu sulit melacak untuk membuktikan sebuah kasus kejahatan telematika dan hal itu selalu ada dalam mengikuti perkembangan teknologi dan sistem yang sulit dijangkau oleh hukum positif.

\section{Bentuk-bentuk kejahatan telematika}

Dalam berbagai sumber sering kita jumpai pernyataan dan terminologi dengan pengertian yang berbeda-beda mengenai kejahatan telematika, Karateristik yang khas dari teknologi telematika juga terus-menerus mengalami perubahan. Bahkan pada era tahun 1980-an saat kejahatan komputer mulai muncul dan menjadi perhatian.

\section{Bentuk bentuk kejahatan komputer :}

1. Data leakage adalah suatu pembocoran data yang dilakukan dengan menulis data tersebut dengan kode-kode tertentu dan tanpa diketahui oleh pihak yang mempunyai tanggungjawab. Misalnya kebocoran tentang data rahasia pada suatu perusahaan, kebocoran data yang dilakukan oleh negara lain untuk sasaran negara tertentu yang sifatnya rahasia. 
2. Data Diddling adalah mengubah data valid/ sah namun caranya yang tidak sah, yang dimaksud "mengubah data" yaitu dengan mengurangkan atau mengubah suatu data untuk tujuan tertentu. Misalnya seorang pegawai computer pada suatu universitas tertentu membantu mahasiswanya dalam mencapai prestasi. Caranya adalah mengubah suatu prestasi akademis yang direkam melalui komputer dengan cara menambah kredit (SKS) atau mengubah pernyataan tidak lulus menjadi pernyataan sebaliknya (lulus).

3. Cyberpiracy adalah penggunaan teknologi komputer dengan mencetak ulang software dengan mendistribusikan informasi tersebut melalui jaringan komputer

4. Cybertrespass adalah penggunaan teknologi komputer dalam mengakses sistem komputer baik organisasi maupun individu dan website tersebut di lindungi oleh password. Contohnya yaitu melakukan sebuah serangan DOS (deniel of service) dalam sebuah web.

5. Cybervandalism adalah penggunaan teknologi komputer dalam membuat program untuk mengganggu proses transmisi sebuah komputer. (Arifah, 2011)

Dari pemaparan bentuk-bentuk diatas seiring dengan berkembangnya teknologi, maka kejahatan yang ada di dunia maya semakin bertambah pada jenisnya, bentuk serta varian-variannya.

\section{Kekuatan Pembuktian Alat Bukti Elektronik}

Sebelum membahas tentang alat bukti elektronik dan dokumen elektronik, seperti yang diketahui bahwa di Indonesia telah memiliki Undang-Undang terbaru yaitu UU Nomor 19 tahun 2016 tentang Informasi dan Transaksi Elektronik, yang menjadi landasan untuk mengatur kejahatan di dunia telematika. Sebelum membahas arti dokumen elektronik, maka perlu mengetahui arti dari computer crime dan computer related crime, arti tersebut sama tapi pengertiannya berbeda. Computer crime (kejahatan komputer) adalah penyalahgunaan teknologi yang memusat (terkonvergensi) pada komputer, media dan informatika, yang didasari motif kriminal atau secara melawan hukum dengan alasan yang tidak dapat dipertanggungjawabkan.

Computer related crime (kejahatan terkait komputer) adalah macam-macam kejahatan tradisional yang diatur dalam Hukum Pidana, kejahatan tersebut diantaranya, pencurian, pembunuhan, korupsi, pencucian uang, dan kejahatan yang terdapat dalam bukti elektronik berupa handpone dan komputer yang digunakan dalam memulai aksinya untuk penyimpanan data atau komunikasi dalam kaitannya dengan perencanaan, proses dan hasil kejahatan tersebut. (wisnubroto, 2010)

Keberadaan informasi/ Dokumen Elektronik yang mengikat dan dapat diakui sebagai alat bukti yang sah serta bisa memberikan kepastian hukum terhadap pelanggaran 
elektronik dan transaksi elektronik. Khususnya dalam informasi elektronik yang hasilnya berupa penyadapan atau perekaman merupakan bagian dalam penyadapan yang harus dilakukan dalam rangka penegakan hukum. Salah satu asas terpentin di dalam KUHAP adalah asas legalitas yang tercermin dalam pasal 3 KUHAP rumusannya yaitu "pengadilan dilakukan dengan vara yang telah diatur dalam undang-undang itu.ketentuan pembuktian diatur dalam pasal 184 KUHAP.

Pengaturan dalam undang-undang khusus mengikat dalam tindak pidana yang diaturnya saja, sehingga hal tersebut hanya sebagai jalan dalam keadaan darurat untuk mengakomodasi tidak hanya hukum materiil tetapi juga hukum formil. (Ramiyanto, 2017)

Dalam Hukum Acara Pidana, kekuatan semua alat bukti pada hakikatnya sama, tidak ada satu melebihi yang lain. Alat bukti dalam hukum acara pidana tidak mengenal hierarki. Hanya saja ada ketentuan-ketentuan yang mensyaratkan keterkaitan antara bukti yang satu dengan bukti yang lain. Di dalam hukum acara pidana terdapat bukti pelengkap. Pada dasarnya pembuktian dikenal sebagai alat bukti universal. Salah satu alat bukti universal di dunia ini adalah dokumen. Dokumen itu tercakup dokumen elektronik jadi tidak hanya di dunia maya termasuk didalamnya hasil hasil cetak (print out) yang merupakan dokumen. Alat bukti elektronik dilakukan verifikasi lebih lanjut mengenai alat bukti dokumen elektronik sama juga dengan verfikasi terhadap alat bukti surat.

Ada tiga hal yang berkaitan dengan dokumen sebagai alat bukti yaitu keaslian dokumen tersebut, isi dari dokumen atau substansinya dengan mencari alat-alat bukti lain yang memperkuat alat bukti dokumen elektronik. Alat bukti informasi elektronik dan dokumen elektronik sangat rentan untuk dimanipulasi. Sehingga keaslian alat bukti informasi elektronik dan dokumen elektronik sangat penting dalam pembuktian.

Alasan kedua, karena sampai saat ini belum ada Standard Operating Procedure (SOP) dalam pengambilan alat bukti elektronik. mengingat kasus-kasus saling berkepaduan dengan media elektronik (cyberspace) dan elektronik sudah berkembang. Media sosial adalah ruang publik sehingga dalam pengambilan segala sesuatu tidak diperlukan izin tertentu karena bersifat publik dan siapapun bisa mengaksesnya. Berbeda dengan e-mail diperlukan izin untuk mengakses data tersebut. Cara mudah tersebut bisa ditempuh oleh penyidik, dengan meminta izin pada pemilik akun. Selanjutnya, ada langkah lain bisa ditempuh yaitu melalui penyedia layanan. pada dasarnya ada perjanjian antara penyedia layanan dan konsumen atau yang dikenal dengan End User License Agreement (EULA).

Pada perjanjian klausula menyebutkan bahwa "konsumen yang melakukan pelanggaran hukum atau tindakan bertentangan dengan aturan maka penyedia layanan boleh menerobos masuk ke akun tersebut".

Dalam penjelasan di atas dapat disimpulkan bahwa dalam hal kekuatan pembuktian, hakim memiliki peranan penting dalam menilai kekuatan dari alat bukti informasi elektronik. 
Hakim terikat dengan minimum pembuktian yaitu dalam menjatuhkan putusan hakim harus berdasarkan 2 alat bukti yang sah diatur dalam Pasal 183 KUHAP. Sehingga keberadaan alat bukti informasi elektronik dan dokumen elektronik memiliki peranan penting dalam pembuktian suatu perkara pidana. (Isma \& Koyimatun, 2014)

\section{Perluasan Alat Bukti Pada Tindak Pidana Dunia Maya}

Dunia internet merupakan dunia digitak yang terdiri dari dunia komunikasi dalam proses yang jauh lebih "virtual" maya. Identitas individu sangat sulit untuk diketahui di dalam dunia digital yang bersifat global. Disini tidak ada sidik jari atau bekas darah yang dapat dianalisa setiap orang. Proses kejahatan di dalamnya bukan tidak berbekas sama sekali, proses komunikasi dan komputasi digital bisa menghasilkan atribut khas, yaitu "benda digital". Pertukaran atribut khas terjadi di dalam proses tindak pidana dunia maya yang berwujud digital. Contohnya yaitu, file dokumen, log akses, email header dsb.

Dunia digital sangat luas cakupannya, sebuah kelompok kerja bernama standard working group on Digital Evidence (SWEDGE) mengartikan bukti digital sebuah informasi yang memiliki nilai pembuktian yang kuat dan disimpan dalam bentuk sinyal-sinyal listrik digital. Perangkat yang menggunakan format data digital sangat banyak. Juga terdapat di dalam ponsel. Smart card bahkan microwave bisa berperan sebagai sumber bukti digital.

Pengakuan terhadap alat bukti digital adalah sebagai berikut :

1. Persoalan tanda tangan pada dokumen

Seperti yang telah diketahui bahwa tanda tangan dalam sebuah dokumen mempunyai peran penting dalam sebuah pembuktian. Dalam prinsipnya, seorang yang mempunyai kontrak jika tidak ada tanda tangannya. Maka kontrak tersebut tidak berlaku jika tidak di tandatangani.

a. Suatu tanda tangan akan berfungsi :

b. Sebagai identitas para pihak

c. Untuk menghubungkan pihak dengan isi dari dokumen yang bersangkutan

d. Memberikan kepastian tentang telah terlibatnya para pihal secara nyata dalam dokumen tersebut.

Menunjukkan tempat kejadian tersebut.

Dalam hubungannya persyaratan hukuman menghendaki tanda tangan bagi suatu dokumen terkait data elektronik, persoalan hukum dianggap cukup jika :

a. Dalam mengidentifikasikan bahwa orang yang dimaksud setuju dengan adanya informasi dalam data elektronik. 
b. Hal tersebut layak dan bisa dipercaya untuk pengunaan data elektronik, dalam mempertimbangkan situasi dan kondisi, termasuk perjanjian yang relevan.

2. Tidak perlu berhadapan muka

Mengingat perkembangan teknologi digital semakin pesat, maka dalam melakukan kontrak tidak perlu lagi bertatap muka, tetapi cukup dengan memakai internet. beda halnya di beberapa Negara dalam melakukan kontrak juga ada yang masih bertatap muka, meskipun tidak tergolong secara khusus.

3. Kewajiban menyimpan dokumen

Hukum mengharuskan pihak tertentu untuk menyimpan data atau dokumen dalam jangka waktu tertentu, Misalya akuntansi atau pajak. Tetapi tidak jarang seseorang yang data tersebut disimpan dalam jangka tertentu, pasalnya tidak jarang data tersebut disimpan dalam bentuk yang sudah dipendekkan atau diubah dalam bentuk yang sudah dipendekkan.

Berdasarkan hal tersebut, maka dapat dilihat bahwa tidak alasan untuk menolak bukti digital sebagai alat bukti yang sah dalam era pembuktian di Indonesia. Maka bukti elektronik dianggap suatu alat bukti yang sah sehingga tercipat kepastian hukum bagi masyarakat Indonesia. Dalam penanganan tindak pidana dunia maya, alat bukti yang digunakan tidak hanya alat bukti yang diatur dalam KUHAP tetapi telah diakui oleh alat bukti yang lain yaitu beruoa informasi elektronik dan dokumen elektronik.

Identitas individu sangat sulit diketahui dalam dunia maya karena bersifat global Yang dalamnya melakukan misi tersebut tidak ada sebuah tanda sidik jari pada si pelaku. Perangkat memiliki potensi untuk menyimpan butki digital selain komputer. Dan terdapat perangkat jaringan lainnya seperti perangkat ponsel, smart card, microwave bisa berperan sebagai sumber bukti digital. (Lasmadi, 2014)

Alat bukti yang sah diatur dalam Kitab Undang-Undang Hukum Acara Pidana (KUHAP) dalam pasal 188 ayat (2) yang dimaksud alat bukti petunjuk yang dapat diperoleh dari :

a) Alat bukti lain yang berupa informasi yang diucapkan, dikirim, diterima atau disimpan secara elektronik dengan alat atau optik yang serupa dengan itu;

b) Dokumen yaitu setiap rekaman data atau informasi yang dapat dilihat diterima, dibaca dan atau didengar yang dapat dikeluarkan dengan atau tanpa bantuan suatu sarana, baik yang tertuang diatas kertas, benda fisik apapun selain kertas, maupun yang terekam secara elektronik, yang berupoa tulisan, suara, gambar, peta, rancangan, foto, huruf, tanda, angka atau perforasi yang memiliki makna. (Natalia, 2015)

Hal ini merupakan perluasan alat bukti petunjuk yang berada dalam undang-undang Nomor 8 Tahun 1981 tentang kitab undang-undang hukum Acara Pidana (KUHAP). 
Macam-macam sumber bukti digital dapat di kelompokkan sebagai berikut:

1. Open komputer system

Perangkat memiliki sistem media penyimpanan yang semakin besar dari waktu ke waktu dan sumber kaya akan bukti digital. File yang sederhana bisa mengandung informasi yang banyak dan berguna bagi para investigasi.

\section{Communication systems}

Telepon tradisional, internet, jaringan komunikasi data merupakan salah satu bukti digital. Sebagai contoh, jaringan internet membawa pesan pesan dari dunia melalui email. Siapa yang mengirimnya, apa isi dari e-mail merupakan bukti digital yang sangat penting dalam investigasi.

\section{Embedded computer system}

Perangkat telepon bergerak dan perangkat lainnya yang tidak dapat disebut komputer tetapi memiliki fungsi seperti komputer dalam cara kerjanya. Disatu pihak hukum harus mengikuti perkembangan zaman teknologi, teknologi digital berfungsi sebagai alat bukti di pengadilan. Dalam hukum pembuktian disebut dengan hukum alat bukti terbaik dan alat bukti digital sulit diterima dalam pembuktian, fotokopi dari suatu surat tidak mempunyai kekuatan pembuktian di pengadilan.

Prinsip hukum yang bersentuhan dengan transaksi elektronik yaang mesti diakui sektor pembuktian sebagai berikut :

a) Informasi elektronik baik dalam bentuk data harus memiliki kekuatan hukum dan bisa mempunyai kekuatan pembuktian seperti dokumen kertas.

b) Kontrak yang dibuat secara elektronik mempunyai kekuatan hukum dan kekuatan pembuktian yang sama dengan kontrak dibuat secara tertulis diatas kertas.

Kriteria atau ketentuan dasar yang harus dipertimbangkan dalam hubungannya dengan pengakuan terhadap alat bukti digital adalah sebagai berikut:

1. Perlakuan hukum terhadap data elekronik.

Dalam hal ini ditentukan bahwa siapapun, baik pengadilan, tidak boleh menolak efek hukum, validitas hukum, dan pelaksanaan hukum semata-mata karena hal tersebut merupakan data elekronik. Di samping itu, pengadilan tersebut tidak boleh menolak efek hukum dari dokumen jika para pihak memang tidak mungkin mendapatkan naskah asli dari dokumen tertentu.

2. Praduga otentisitas.

Prinsip praduga otentisitas ini merupakan suatu ketentuan yang sering digunakan untuk membuktikan keaslian suatu dokumen/ data digital atau keaslian tanda tangan digital. Hukum pembuktian beranggapan bahwa dokumen atau tanda tangan digital dianggap asli, kecuali dapat dibuktikan sebaliknya. Yang dilakukan dalam hal ini adalah suatu pembuktian

al-ạ̣kām Vol. 3, Nomor 1, 2018 
terbalik. Artinya, barang siapa yang menyatakan bahwa alat bukti tersebut palsu, maka dialah yang harus membuktikannya. Dengan demikian, sebagai konsekuensi dari prinsip ini adalah bahwa pengadilan tidak boleh menolak alat bukti digital hanya karena itu adalah bukti digital, tetapi jika ingin ditolak, pihak yang keberatan atas bukti tersebut harus mengajukan alasan-alasan yang rasional, misalnya dengan membuktikan bahwa alat bukti digital tersebut sebenarnya adalah palsu atau hasil rekayasa saja;

3. Notarisasi bisnis.

Notarisasi bisnis terhadap suatu alat bukti digital juga sering dipersyaratkan oleh hukum pembuktian. Yang dimaksud dalam notarisasi bisnis adalah pelibatan notaris atau petugas khusus untuk itu, setelah dilakukan penelaahan, pemeriksaan pemakaian standar tertentu, notaris atau petugas khusus menyatakan bahwa data atau tanda tangan digital tersebut adalah benar ditandatangani oleh pihak yang tertulis sebagai penandatangannya. (Mansur \& Gultom, 2005)

Ada tiga hal yang dapat dijadikan panduan dalam menggunakan bukti elektronik dalam suatu perkara yang terjadi di dalam transaksi elektronik :

a) Adanya modus operandi yang sama dalam melakukan tindak pidana dengan menggunakan komputer.

b) Adanya persamaan antara satu peristiwa satu dengan lainnya.

c) Adanya motif (dalam melakukan tindak pidana)

Beberapa cara suatu transaksi elektronik dalam pengadilan pidana dapat diterima menjadi bukti, antara lain :

1. The real evidence route

Suatu bukti elektronik sebagai alat bukti yang sah dan berdiri sendiri dapat memberikan jaminan rekaman/salinan data berjalan sesuai dengan prosedur yang berlaku sehingga hasil printout suatu data bisa diterima dalam pembuktian suatu kasus.

2. The statutory route

Denga pedoman suatu penetapan atau pengesahan data suatu bukti elektronik daoat diterima sebagai bukti di pengadilan.

3. The expert witness

Dalam peranan saksi ahli adalah bahwa seorang ahli dapat menjadi alat bukti suatu kasus, dimana keterangan tersebut berdasarkan pengetahuan dan pengalaman. Kesaksian dapat dijadikan pertimbangan hakim terutama pembuktian tersebut dinilai keakuratannya.

Ketiga pola tersebut harus ada dalam pemeriksaan suatu kasus di dalam pengadilan. Dilihat keberadaan data elektronik akan sangat lemah jika tidak didukung ketiganya secara bersamaan. 


\section{Kesimpulan}

Dalam pengunaan sistem pembuktian alat-alat bukti berdasarkan pasal 184 KUHAP yang mampu menjangkau pembuktian untuk kejahatan siber (cyber crime) adalah tergolong tindak pidana baru. Penelusuran terhadap alat alat bukti konvensional seperti keterangan saksi dan saksi ahli, juga bergeseran surat dan petunjuk dari konvensional menuju elektronik akan mampu menjerat pelaku kejahatan siber (cyber crime). Hal tersebut tentu saja membutuhkan kecermatan para penegak hukum dalam menggunakannya kemudian dapat diajukan dan diterima oleh hakim. Tidak terlepas dari sifatnya ada tindak pidana baru, maka kejahatan cyber crime pada akhirnya membutuhkan ketentuan yang baru agar alat bukti elektronik dapat diterima sebagai alat bukti yang sah.

Dalam pembuktian pidana tidak mengenal pembuktian bebas. Hakim memiliki hak untuk menilai alat bukti yang dihadirkan dalam persidangan. Hakim terikat dengan minimum pembuktian yaitu dalam menjatuhkan putusan hakim harus berdasarkan 2 alat bukti yang sah diatur dalam pasal 183 KUHAP. Sehingga keberadaan alat bukti informasi elektronik dan dokumen elektronik mememiliki peranan penting dalam pembuktian suatu perkara pidana.

Dokumen elektronik yang dapat diterima sebagai alat bukti. yang dimaksud pada pasal 1 nomor 2 Undang-Undang Nomor 19 tahun 2016 tentang Informasi dan Transaksi Elektronik suatu perbuatan yang dilakukan menggunakan komputer atau media elektronik lainnya. Dalam rangka melakukan transaksi elektronik, maka para pihak akan selalu menggunakan suatu dokumen elektronik sebagai landasan bagi mereka untuk melakukan hubungan hukum. Sistem hukum pembuktian sampai saat ini masih menggunakan ketentuan hukum yang lama, dan belum mampu menjangkau pembuktian atas kejahatan-kejahatan yang berlaku di lingkungan dunia maya. Namun keberadaan Undang-Undang No. 8 tahun 1997 tentang Dokumen Perusahaan telah mulai menjangkau ke arah pembuktian dalam data elektronik. Walaupun Undang-Undang tersebut tidak mengatur masalah pembuktian, pemerintah berusaha mengatur pengakuan atas microfim dan media lainnya.

semua alat bukti pada hakikatnya sama, tidak ada satu melebihi yang lain. Alat bukti dalam hukum acara pidana tidak mengenal hierarki. Hanya saja ada ketentuan-ketentuan yang mensyaratkan keterkaitan antara bukti yang satu dengan bukti yang lain. Di dalam hukum acara pidana terdapat bukti pelengkap. computer crime dan computer related crime, arti tersebut sama tapi pengertiannya berbeda. Computer crime (kejahatan komputer) adalah penyalahgunaan teknologi yang memusat (terkonvergensi) pada komputer. 


\section{DAFTAR PUSTAKA}

Mansur, Dikdik M. Arief \& Gultom, Elistaris. 2005. Cyberlaw Aspek Hukum Teknologi Informasi, Bandung : raflika aditama

Al. Wisnubroto, Strategi Penanggulangan Kejahatan Telematika. 2010. Yogyakarta : Atma jaya

Jurnal

S Hamdi, M Suhaimi dan Mujissalim, 2013, "Bukti Elektronik dalam Sistem Pembuktian Hukum Pidana", Jurnal Ilmu Hukum, vol.1 (4) diakses pada 12 April 2018 dari http:// www.jurnal.unsyiah.ac.id/MIH/article/view/

Muhammad danuri, 2017, Trend Siber (Cyber Crime) dan Teknologi Informasi di Indonesia, Infokam, No.2, XIII, Infokam akses pada 11 April 2018 dari http://amikjtc.com/ jurnal/index.php/jurnal/article/view133

Michael Barama, 2014, Elektronik sebagai Alat Bukti Yang Sah, Manado, akses pada 11 April 2018 dari website http://repo.unsrat.ac.id/68/1/1/

Abdullah, Gelombang Online Dalam Perkembangan Hukum diakses pada 14 April 2018 dari https://www.mahkamahagung.go.id/id/artikel/2830/

Nur laili Isma, Arima Koyimatun, 2014, Kekuatan Pembuktian Alat Bukti Informasi Elektonik pada Dokumen Elektronik serta Hasil Cetaknya dalam Pembuktian Tindak Pidana," Jurnal penelitian hukum", Vol.1(2), diakses pada 14 April 2018 dari website https:// media.neliti.com/media/publications/122959-ID-none.pdf/

Cahyo Handoko, 2016, "Kedudukan Alat Bukti Digital dalam Pembuktian Cyber crime di Pengadilan", Jurisprudence, Vol.6 (1) diakses pada 15 April 2018 dari http://journals. ums.ac.id/index.php/jurisprudence/article/

Johan Wahyudi, "Dokumen Elektronik sebagai Alat Bukti pada Pembuktian di Pengadilan", perspektif, Vol XVII (2), diakses pada 13 April 2018 dari http://jurnal-perspektif.org/ article/view/

Ramiyanto, "Bukti Elektronik Sebagai Alat Bukti Yang Sah Dalam Hukum Acara Pidana", 2017, jurnal hukum dan peradilan, Vol.6, No.3, diakses pada 15 April 2018, dari website : http://scholar.google.co.id

Sahuri Lasmadi, "pengaturan Alat Bukti Dalam Tindak Pidana Dunia Maya", Jurnal Ilmu Hukum, 2014, Diakses pada 5 Juni 2018 dari website online -journal.unja.ac.id

Dista Amalia Arifah, "Kasus Cybercrime Indonesia", 2011, Jurnal Bisnis dan Ekonomi, Vol.18, No.2 diakses pada 5 Juni 2018, dari Website https://media.neliti.com

\section{Undang- undang}

Kitab Undang-Undang Hukum Acara Pidana

KUHP

Kitab Undang-Undang hukum Acara Perdata

UU Nomor 19 tahun 2016 tentang Informasi dan Transaksi Elektronik

UU Nomor 8 Tahun 1997 Tentang Dokumen Perusahaan 
al-ahkām vol. 3, Nomor 1, 2018 